\title{
Research on Rural Fathers' Involvement in Early Childhood Education in China-Based on a Survey on 400 Families
}

\author{
Jihui $\mathrm{Gu}^{1}$ \\ ${ }^{1}$ Department of Education Science, Yibin University, Yibin, Sichuan, China \\ Correspondence: Jihui Gu. E-mail: 2001109004@ yibin.edu.cn
}

Received: August 23, 2020

Accepted: September 9, 2020

Online Published: September 29, 2020

doi:10.5539/ass.v16n10p85

URL: https://doi.org/10.5539/ass.v16n10p85

\begin{abstract}
To understand rural fathers' involvement in early childhood education, an anonymous self-report questionnaire was distributed to 400 fathers of children in six kindergartens in Sichuan Province. Mean of the scale is 3.78, in which the subscale of Mother Support (4.09 \pm 1.06$)$ scores the highest, while Attentiveness $(3.28 \pm 0.88)$ scores the lowest. Fathers different in education, occupations and number of children involves in children's education differently. It was found that rural fathers' involvement in early childhood education of Sichuan is comparatively low. It is necessary to reveal the factors hindering their participation through further research and find methods to improve it.
\end{abstract}

Keywords: rural father, involvement, early childhood

\section{Introduction}

In traditional Chinese culture, role of a father includes strict family leader, moral teacher, economic provider and model of gender role. Meanwhile, Chinese society now pays more attention to fathers' duty of co-parenting with mothers during the growth of children (Wu, 2012, p. 56). The research on fathers' involvement in children's education includes the present situation, the factors affecting it and its influence to children's development, etc. (Xu, 2006, p. 12; Ye, 2013, p. 59). Many studies have found that fathers' participation in parenting in China is at a medium or high level (Xu, 2010, p. 46; Xu \& Liang, 2008, p. 72; Sylvia, 2013, p. 1051; Li, 2016, p. 4). However, these studies are mostly on fathers from urban or developed suburban areas. The only studies take rural children as samples to judge the status of fathers' involvement indirectly. (Zhou, 2015, p. 27; Li, 2015, p. 1492) None of them has directly studied the participation of fathers through their self-reported reports.

One of the important issues hindering the study is the difficulty of sampling. Most fathers in rural areas choose to work in cities for higher salaries. Therefore, they cannot participate in the survey. As for the fathers at home, busy work and being too less educated to understand the questionnaire makes the survey even harder. Since fathers' involvement in early childhood education is of great significance to children's development, it is also necessary to understand the influence and role of fathers in rural areas. Through a sample survey of 400 infant families, this study hopes to preliminarily reveal the situation of rural fathers' involvement in early childhood education in Sichuan to emphasize the significance of fathers' participation, and provide reference for kindergartens or related institutions to cooperate accordingly.

\section{Methods}

\subsection{Participants}

Four hundred children were selected from six rural kindergartens in Bazhong, Luzhou, Guangyuan, Chengdu and Yibin to investigate their families. A total of 400 questionnaires were issued and 343 were recovered. 56 invalid questionnaires with incomplete data were excluded, and 287 valid questionnaires were collected, with the effective questionnaire recovery rate of $71.75 \%$.

\subsection{Scale}

The Inventory of Father Involvement designed by Hawkins and edited by Xu Yan (2006, p. 35) was used in this study. There are 5 subscales including Attentiveness (A), Discipline\& Responsibility (DR), Praise \& Affection (PA), Mother Support (MS) and School Encouragement (SE) in which 7 points system is used: 0 anchored by "Very Poor" and 7 anchored by "Excellent". The higher the score, the more involved the father was in parenting. 
The study shows that the internal consistency coefficient of the questionnaire is 0.94 , and the internal consistency coefficient of the five subscales is 0.74 0.92. The reliability of the questionnaire is good.

\subsection{Procedure}

The questionnaire was handed out to the kindergarten by senior students from The School of Psychology who had received training. After some notices, the questionnaires were handed out on spot to the parents who take them home and finish within a week.

\subsection{Statistical Method}

SPSS 21.0 was used to input the collected data. Descriptive statistics and difference significance test were conducted.

\section{Results}

\subsection{Descriptive Statistics on the Involvement of Rural Fathers in Early Childhood Education}

The result shows that the mean of rural fathers' involvements areas is 3.78. Among the five subscales, MS scores the highest while the lowest score4 is A, and the rest are DR, PA and SE from top to bottom.

By analyzing the means of each item in five subscales (Table 1), the present situation of fathers' involvement in preschool education in rural areas can be revealed. In the highest-scored scale of MS, "Financial Support" scores the highest and "Basic needs" scores the lowest. DR is the second highest subscale with the two highest scored items - "Telling children to listen to teachers in kindergartens" and "behave well in kindergartens", while the lowest scored items are "Set rules to regulate children's behavior" and "Emphasize family rules". As for "PA", fathers do the best in "Timely praise when children are well-behaved", while they are not good at "Verbalize love". On the SE subscale, "Encourage reading" and "Encourage children to get into college when they grow up" scored significantly higher than "Planning for children's future." Scores from A subscale showed that the fathers prefer to supervise instead of interact with children. The highest scored item is "Know children's favorite books and TV programs", and then "Know children's playmate and daily activity". Fathers scores generally low in this subscale, in which "Tell children stories" scores the lowest.

Table 1. Descriptive statistics on the rural fathers' involvement in early childhood education

\begin{tabular}{|c|c|c|c|c|c|}
\hline \multirow{2}{*}{ item } & \multicolumn{5}{|c|}{$\mathrm{M}+/-\mathrm{SD}$} \\
\hline & A & DR & $\mathrm{PA}$ & MS & SE \\
\hline $\begin{array}{c}\text { Know children's favorite books and } \\
\text { TV programs }\end{array}$ & $4.23+/-1.36$ & & & & \\
\hline $\begin{array}{l}\text { Know children's playmate and } \\
\text { daily activity }\end{array}$ & $3.78+/-1.40$ & & & & \\
\hline $\begin{array}{l}\text { Encourage children to develop their } \\
\text { talents }\end{array}$ & $3.76+/-1.34$ & & & & \\
\hline Keep an eye on children's activities & $3.57+/-1.38$ & & & & \\
\hline Listen to children's perspectives & $3.52+/-1.41$ & & & & \\
\hline Make friends with children & $3.43+/-1.35$ & & & & \\
\hline Take care of children's daily life & $3.33+/-1.66$ & & & & \\
\hline $\begin{array}{l}\text { Help identify children's goals and } \\
\text { directions }\end{array}$ & $3.29+/-1.69$ & & & & \\
\hline $\begin{array}{l}\text { Talk to children about their daily } \\
\text { lives }\end{array}$ & $3.25+/-1.51$ & & & & \\
\hline Help children with their homework & $3.20+/-1.59$ & & & & \\
\hline $\begin{array}{l}\text { Take children somewhere } \\
\text { interesting }\end{array}$ & $3.14+/-1.42$ & & & & \\
\hline $\begin{array}{l}\text { Make time for your child to do } \\
\text { what they want to }\end{array}$ & $3.03+/-1.33$ & & & & \\
\hline
\end{tabular}


Make time to talk to children

Do housework together

Tell children stories

Tell children to listen to their teachers

Tell children to behave well in kindergartens

Encourage children to finish his homework

Teach children to be responsible for what they do

Supervise children

Encourage children to tidy up their toys

Set rules to restrain children's behavior

Emphasize the family rules

Timely praise when children are well-behaved

Timely praise when children make the right decision

Use body language to express feelings to children

Tell your children you love them Financial support

Rear children with the mother

Aware children of the importance of the mother

Provide encouragement and emotional support to the mother Meet your children's basic needs

Encourage children to read more books

Encourage children to go to colleges

Plan for children's futures
$2.85+/-1.24$

$2.51+/-1.39$

$2.37+/-1.35$

$4.58+/-1.28$

$4.32+/-1.39$

$4.27+/-1.54$

$4.13+/-1.25$

$4.02+/-1.36$

$3.54+/-1.47$

$3.20+/-1.48$

$2.52+/-1.68$

$4.15+/-1.32$

$4.08+/-1.30$

$3.82+/-1.72$

$2.99+/-1.63$

$4.36+/-1.43$

$4.02+/-1.63$

$3.96+/-1.62$

$3.94+/-1.60$

$3.77+/-1.26$

$4.08+/-1.458$

$4.05+/-1.659$

$2.79+/-1.838$

$3.64+/-1.21$

\subsection{Differences Between Rural Fathers' Involvement in Early Childhood Education}

In exploring the possible differences of education level, occupation and number of children in this sample on the domains of the total score and sub-score of fathers' involvement, it is found, as summarized in Table 2.

ANOVA confirms that fathers with different education levels have significant differences in the scores of A and PA $(\mathrm{P}<0.01)$. Post-hoc analyses show that college-educated men pay more attention to their children than the others. Fathers with college degrees score significantly higher on PA than those only have received elementary or junior high school education.

ANOVA shows significant differences in involvement of fathers in different occupations $(\mathrm{P}<0.01)$. Post-hoc 
analysis finds that civil servants scores significantly higher on A than the others, and they score significantly higher on DR than company staffs and freelancers.

The $t$ test comparisons reveal that fathers with multiple children scores significantly higher on the SE subscale than fathers with only one child, and on the PA subscale, the two groups scores nearly significantly, with only fathers with one child showing more praise and affection to their child.

Table 2. Differences between rural fathers' involvement in early childhood education

\begin{tabular}{|c|c|c|c|c|c|c|c|}
\hline $\begin{array}{c}\text { Demograp } \\
\text { hic } \\
\text { indicator }\end{array}$ & Number & statistics & A & DR & PA & MS & SE \\
\hline \multirow{6}{*}{$\begin{array}{l}\text { By The } \\
\text { level of the } \\
\text { education }\end{array}$} & Primary school (21) & & $3.11+/-1.09$ & $4.00+/-0.77$ & $3.68+/-1.37$ & $3.90+/-1.28$ & $4.10+/-1.22$ \\
\hline & $\begin{array}{c}\text { Junior High School } \\
\text { (142) }\end{array}$ & & $3.13+/-0.76$ & $3.71+/-0.87$ & $3.57+/-1.19$ & $4.00+/-1.07$ & $3.56+/-1.21$ \\
\hline & $\begin{array}{c}\text { Senior High school } \\
(80)\end{array}$ & & $3.31+/-0.85$ & $3.84+/-0.87$ & $3.84+/-1.13$ & $4.12+/-1.02$ & $3.53+/-1.22$ \\
\hline & University (44) & & $3.82+/-0.98$ & $4.06+/-0.93$ & $4.23+/-1.03$ & $4.46+/-0.97$ & $3.86+/-1.17$ \\
\hline & & $F$ & 7.67 & 2.31 & 4.05 & 2.37 & 1.93 \\
\hline & & sig & 0.000 & 0.077 & 0.008 & 0.071 & 0.125 \\
\hline \multirow{7}{*}{ occupation } & Farmer (57) & & $3.13+/-0.83$ & $3.94+/-0.82$ & $3.51+/-1.35$ & $4.04+/-1.05$ & $3.63+/-1.21$ \\
\hline & Self-employee (72) & & $3.11+/-0.82$ & $3.66+/-0.90$ & $3.72+/-1.18$ & $4.17+/-1.18$ & $3.52+/-1.23$ \\
\hline & Freelancer (86) & & $3.43+/-0.72$ & $3.88+/-0.76$ & $3.79+/-1.02$ & $4.02+/-0.95$ & $3.66+/-1.20$ \\
\hline & Company Staff (47) & & 3. $02-0.82$ & $3.57+/-0.98$ & $3.85+/-1.23$ & $3.99+/-0.96$ & $3.49+/-1.18$ \\
\hline & Civil Servant (25) & & $4.09+/-1.22$ & $4.27+/-0.96$ & $4.17+/-1.63$ & $4.45+/-1.29$ & $4.20+/-1.18$ \\
\hline & & $F$ & 8.87 & 3.61 & 1.47 & 1.02 & 1.71 \\
\hline & & sig & 0.000 & 0.007 & 0.210 & 0.398 & 0.148 \\
\hline \multirow{4}{*}{$\begin{array}{l}\text { Number of } \\
\text { children }\end{array}$} & One (139) & & $3.33+/-0.93$ & $3.74+/-0.94$ & $3.88+/-1.19$ & $4.01+/-1.16$ & $3.49+/-1.31$ \\
\hline & Two or more (148). & & $3.24+/-0.83$ & $3.90+/-0.81$ & $3.64+/-1.17$ & $4.18+/-0.97$ & $3.77+/-1.10$ \\
\hline & & $t$ & 0.921 & 1.593 & 1.746 & 1.342 & 1.989 \\
\hline & & sig & 0.358 & 0.112 & 0.082 & 0.181 & 0.048 \\
\hline
\end{tabular}

\section{Discussion}

The results indicate that the rural fathers' involvement is less than that of Hong Kong fathers (Sylvia, 2013, p. 1054) and urban fathers in mainland China (Xu, 2010, p. 48). It is hypothesized that the rural areas are geographically isolated and mainly influenced by conventional instead of modern view on education. Besides, the less educated fathers are not fully aware of what their participation means in children's early childhood education. Relevant department of the government and social groups need to take varieties of measures to help fathers realize their duty and encourage them to involve more. Among all 5 subscales, MS scored the highest, which is highly consistent with the research results of Fan (2018). On the contrary, subscale A scores the lowest and was consistent with the research results of Li Zhen et al. (2015, p. 1492). Gap between two subscales indicates that rural fathers, influenced by traditions, still play the role of financial supporter, and involve in early childhood education mainly by supporting mothers. They have not yet used to co-parent as the society now requires them to. As for items in A subscale, fathers prefer to supervise instead of interact with their children. The reason is that, in addition to the outdated concept of parenting mentioned above, it may also be due to their role as a breadwinner, which doesn't allow them enough spare time. Fathers also scored lower for SS, with the highest score being for encouraging their children to go to college later in life. As the famous Chinese saying goes, "knowledge changes fate". Parents often regard admission to university as the only proof of a child's success. Meanwhile, the present employment market in China, which is generally based on academic background, determines that a bachelor's degree is a stepping-stone for young people to find a decent job. Most of the fathers in this survey have only received education below junior high school and have spent most of their 
lives in hometowns. They may expect their children to move to cities after they are admitted by universities instead of being famers. The score of planning for children's future is low, which indicates that although rural fathers keep attaching importance to children's study, they are still lack of participation, because it may be much beyond their ability to plan their children's future. As a result, they can only encourage their children to go to college verbally.

The results also indicate that fathers with different education have statistically significant differences in their involvement. The lower the education level is, the lower the A and PA scores are, which was consistent with previous studies $(\mathrm{Li}, 2015$, p. 1492).The less educated the fathers are, the more difficult it is for them to recognize how significant they are in the developments of children and therefore pay little attention to them. They prefer to follow the tradition instead coparenting. Meanwhile, they may not understand how to interact with children properly according to their development stages and are more likely to ignore children's emotional needs. For them, methods such as avoidance, blame, command or even abuse are much easier rearing skills. It is worth noting that improving the education level of rural fathers may promote their effectiveness in early childhood education. The survey also found a statistically significant difference in the level of parenting participation among fathers of different occupations. Fathers working in government departments and fathers engaged in freelance work scored significantly higher in A than other fathers. In the subscale of DR, the scores of civil servants are significantly higher than those in other professions, and the scores of fathers in companies are all low. For civil servants, the working schedules are stipulated by the government, garneting them enough spare time to get along with children so that they can have more opportunities to interact and regulate children's behavior through activities. However, most of the enterprises in rural areas are privately owned and working hours are determined by the owners themselves. Which are generally longer and usually without weekends off. As a result, the fathers in these companies spend less time at home and lack opportunities to interact with their children (Gu, 2020, p. 111). By instituting regulations to limit working hours in private companies, fathers' involvement in parenting may be increased. Studies have produced inconsistent results on the impact of the number of children on fathers' involvement. The study indicates that compared with fathers with only one child, rural fathers with two children or more offer their children more school encouragement. Tan Junwen (2017, p. 590) et al. also found that fathers with multiple children have a higher degree of participation in child rearing, which is consistent with the results of this study. Zhou Lei $(2015$, p. 29) found that fathers with only one child scored higher in SS, which was on the contrary. According to Li Zhen (2015, p. 1493), there was no statistical difference between the two, which was inconsistent with the results of this study. Such inconsistency may be explained by the difference of the samples. Zhou Lei's subjects include cities, towns and rural fathers, in which father with only one child from cities are the majority. They are generally better educated, and have more time for interaction compared with rural fathers. Also, they are more capable of giving their children more instructions and encouragement. The number of fathers with only one child in Li Zhen's research is quite small, which may have some deficiencies in representativeness. The samples of this study are all from rural areas, and the number of fathers with only one child was close to that of fathers with multiple children. The results of this survey show that when the number of children increases, rural fathers will participate more in parenting, and mainly provides school encouragement for children. Being fathers of multiple children requires them of more support of finance and children rearing. Therefore, they turn to encourage children to study hard at school, go to college and find a decent job, which will definitely reduce their burden.

\section{Conclusion}

Rural fathers' involvement in early childhood education is moderate and lower than that of urban fathers. Less educated and fathers working in companies are less involved, and their involvement increases when the number of children increases. Further research should focus on understanding the factors that hinder their involvement and finding methods to improve it, so as to ensure the mental and physical health of children in rural areas.

\section{Acknowledgement}

Fund project: Center for Rural Childhood Education Research General Project (No. NYJ20140606).

\section{References}

Fan, H. F. (2018). The research between father involvement and early reading interest behavior in children aged four to six years old (Unpublished Master's Thesis). Henan Normal University, Henan, China. https://doi.org/10.7666/d.D01417425

Gu, J. H. (2019). Obstacle and breakthrough of father's involvement in early childhood education: An analysis on families with different structures. Asian Social Science, 16(1), 109. https://doi.org/10.5539/ass.v16n1p109 
Li, T. T., \& Yuan, L. (2016). Investigation on Father Involvement - A Case Study of Urban Kindergartens in Changsha County. Asia-pacific Education, (27), 4-4. https://doi.org/10.16550/j.cnki.2095-9214.2016.27.005

Li, Z., Chen, Y. L., Liu, Q. L., \& Lei, Y. H. (2015) Impact of Patturance on self-esteem Development among Rural pupils. Chinese Journal of School Health, 36(010), 1492-1495. https://doi.org/10.16835/j.cnki.1000-9817.2015.10.019

Kwok, S. Y., Ling, C. C., Leung, C. L., \& Li, J. C. (2013). Fathering self-efficacy, marital satisfaction and father involvement in Hong Kong. Journal of Child and Family Studies, 22(8), 1051-1060. https://doi.org/10.1007/s10826-012-9666-1

Tan, J. W., Li, H., \& Yan, L. N. (2017). Relationship Between Father Involvement and scholastic self-efficacy. China Journal of Health Psychology, (4), 28. https://doi.org/10.13342/j.cnki.cjhp.2017.04.028

Xu, Y. (2010). Urban Father's Involvement on the Education of Children. Studies in Early Childhood Education, (7), 46-50. https://doi.org/10.13861/j.cnki.sece.2010.07.016

Xu, A. Q., \& Zhang, L. (2008). Rural Father's Will, Acts and Experience of Parenting - Experienced Research of Shanghai's Suburbs. Journal of Social Science of Hunan Normal University, 37(3), 72-76. https://doi.org/10.3969/j.issn.1000-2529.2008.03.016

Xu, Y., Ji, L. Q., \& Zhang, W. X. (2006). Urban Fathers' Involvement in children-parenting and its Relationship with Gender Roles. Psychological Development and Education, 22(3), 35-40. https://doi.org/10.3969/j.issn.1001-4918.2006.03.007

Xu, Y., \& Zhang, W. X. (2006). A Review of Studies on Fathers' Involvement. Education Research, (1), 12-14. https://doi.org/10.3969/j.issn.1674-2311.2006.01.003/

Ye, Q. Q., \& Xu, H. (2013). Research on Father Involvement in T Children's Education: Involvement and Prospect. Journal of Basic Education Research, (15), 59-61.

Zhou, L., Chen, Y. L., Liu, L. R., \& Qiu, N. (2015). Effect of Father Involvement in Parenting on Primary School Students' Quality of Life. Journal of Chengdu Normal University, 31(8), 27-32. https://doi.org/10.3969/j.issn.2095-5642.2015.008.027

\section{Copyrights}

Copyright for this article is retained by the author(s), with first publication rights granted to the journal.

This is an open-access article distributed under the terms and conditions of the Creative Commons Attribution license (http://creativecommons.org/licenses/by/4.0/). 